\title{
RISK IN THE SCOPE OF RESEARCH AND INNOVATIVE TECHNOLOGICAL PROJECTS
}

\author{
Maria Richert \\ AGH University of Science and Technology, Faculty of Management \\ 10 Gramatyka St., 30-067 Cracow, Poland, mrichert@agh.edu.pl \\ (D) https://orcid.org/0000-0003-2233-6923 \\ Rafat Hubicki \\ Grupa Kęty S.A. \\ 111 Kościuszki St., 32-650 Kęty, Poland \\ Piotr Łebkowski \\ AGH University of Science and Technology, Faculty of Management \\ 10 Gramatyka St., 30-067 Cracow, Poland \\ Joanna Kulczycka \\ Mineral and Energy Economy Research Institute Polish Academy of Sciences \\ 7a Wybickiego St., 31-261 Cracow, Poland \\ (D) https://orcid.org/0000-0002-4377-5506 \\ Asja Mrotzek-Bloess \\ Clausthal University of Technology \\ 9 Walther-Nernst-St, 38678 Clausthal-Zellerfeld, Germany
}

\begin{abstract}
Assessment and management of risk constitute the subject of many researches. Nevertheless, many more specific factors are applicable during the implementation of innovative technological projects. On the article identified risk factors, which have been supplemented, systematized and assigned to the individual risk categories. The risk assessment methods for R\&D projects have been analysed, as well as the risk sheets have been developed for the R\&D project through the use of dotProject application. Also shown that networking and clustering is a change for fruitful cooperation within difference EU projects, which create trust between business and sciences and reduce the risk.
\end{abstract}

\section{Keywords}

risk management, technological projects, innovations, research and development, cooperation

\section{Introduction}

One of the significant areas of enterprises' business activity is risk management, including limitation and reduction of its negative consequences, which may appear in various areas of business activity. The literature distinguishes many types of risk classification, related to business and financial activity. In more detailed aspect, it is possible to distinguish technical risk, management risk (for example: macroeconomic risk, legal risk, e.g. associated with increasing requirements in the scope of environmental protection), financial risk, organisational risk and technological risk. In the case of implementation of the technological innovations (product or process innovations), it is necessary to note the following: investment risk, risk of the lack of social acceptance or risk occurring in the supply chain.

For the purpose of limiting the consequences and improving the risk management processes, the ISO 31000:2009 standard concerning the risk management system has been developed, which was amended in 2018 (ISO 31000:2018, Risk management - Guidelines). Moreover, ISO published a new standard - ISO IEC 3110 Risk management - Risk assessment techniques in 2019, which offers more than 30 various techniques allowing for the identification and management of risk.

In addition, the risk management is an integral part of many project management methodologies, e.g. PRINCE 2, PMI or Ten Step. The PRINCE 2 methodology recommends that each project should have its own risk 
management strategy (that determines the risk management procedure adopted by the project, from its determination to the implementation), along with the control measures, i.e. risk register. The PRINCE 2 method proposes a risk management procedure that consists of 5 stages: identification, assessment, response planning, response plan implementation and communication, which is a repetitive task [2]. It is commonly used for project management, however much more specific factors may occur during the implementation of innovation, and they should be identified, as well as estimated. In the process of managing the innovative R\&D projects, the key aspect consists of risk identification and assessment, while it should be taken into account that due to R\&D, an enterprise can provide growth, profitability and survival to itself. There are also many instruments of EU policy related to innovation, fostering research and development or technology support by promoting collaboration between research and business, which can reduce the risk. [16, 19]

\section{Methods}

On the basis of literature review, analysis of research project documentations and experience of R\&D project managers, the proposed risk management methods, identification and assessment of risk, as well as risk management methods have been reviewed. This allowed identifying the factors specific for R\&D projects, which may affect the level of risk during the implementation of innovative technological projects. For the purpose of their systematisation, the analysed factors have been assigned to the individual risk categories, as well as the risk assessment methods for R\&D projects have been analysed. Through the process of identifying risk factors and management methods for the selected case study, and through the use of dotProject application, the risk sheets have been developed for the R\&D project implemented by the production company engaged in the manufacture of products made of aluminum. Besides, the technological and economic aspects connected with risk assessment, the organisational one, connecting with the integration of business, academic and research community to build long-term cooperation is discussed.

\section{Identification and assessment of risk}

For R\&D projects, the literature indicated that the important problem in risk management of R\&D projects is the difficulties in identifying and prioritizing R\&D risks, because most of the R\&D ideas are fuzzy, and the project management of R\&D is largely poorly organized, forcing the waste of time and cost [14]. Moreover, the concept of risk has no unequivocal definition in practice [1]. The basic activity in the scope of risk assessment is its estimation, which is not synonymous with the protection against risk. It must be emphasised that in practice, there are no undertakings that would be risk-free, therefore firstly it is necessary to estimate the level of risk occurring during the implementation of projects. The simplest classification includes:

- low risk - occurs in the case of projects that are implemented with the use of previously applied methods, while the intended effects were previously achieved in other projects,

- moderate risk - occurs in the case of implementation of undertakings, which use so far unused methods, however the intended results are known from previous projects; this level of risk also occurs in the situations, in which we use previously used methods, but with intended results other than those achieved before,

- high risk - occurs in the case of using methods that were not previously implemented, while the intended effects are also completely new.

The risk assessment and classification methods include probability and impact method, risk sheets, expert assessment method, decision trees, cause and effect diagrams (e.g. PERT - Time, PERT - Cost, CPMO) and Monte Carlo method. In the case of a large number of threats, it is necessary to focus on the ones that are the most threatening to the project. The risk level is obtained by multiplying the weight of the project by the probability of risk occurrence. Moreover, it is necessary to prepare a tabular listing of all identified risks, which allows obtaining the project's risk profile. During assessment of the risk level or during preparation of its profile, it is important to select the person among those participating in the project, who will have the competence to determine the probability value, weight and limit value separating the acceptable risks from unacceptable risks or hardly-acceptable risks. Most often, this is the person managing the project. The risk management plan is approved by the steering committee (or the sponsor in the case of a project structure without steering committee) and it also decides on the level of risk acceptability. The project manager is the person preparing the risk management plan. [20] 
2. Specific characteristics of R\&D projects and their impact on the level of risk

$R \& D$ projects are characterised by a very high degree of dispersion, because they can be implemented, among others, by academic centres, universities, institutes and scientific societies, enterprises, libraries, museums and national parks. A big challenge is to popularise the project management theory in the scope of implementation of these projects (maybe except for research teams operating in the scientific centres of large corporations, which have a strictly defined organisational structure), because they are highly dependent on the human factor. Experiences demonstrate that brainstorming can bring the opposite results to the expected ones - too many ideas, positions, views and instances of proving 'your own point', can threaten the successful completion of the project. Project management methodologies, e.g. PRINCE 2, usually operate with the use of too general concepts, leaving many matters for the individual assessment by the project leader. This results in the doubts concerning entrusting the project to persons who lack the appropriate expert knowledge.

For determining the sources of risk in the project, it is very helpful to adopt some systematics in the scope of project's risk categories. These include the groups of potential risk sources, which are associated with their occurrence during the project implementation. For the purposes of project risk management, the following risk categories are proposed:

- Technical risk resulting from technical aspects of the project implementation. In their nature, the research projects are burdened by high technical risk. This results from the fact that they are seeking to discover previously undetermined new correlations, which no one has ever studied before, and they also undermine the existing material and its claims, prove the functioning of other correlations, as well as attempt to expand the existing research,

- Project management risk resulting from actions undertaken at the project planning stage (project planning risk) and from actions undertaken as part of the project implementation (project implementation risk),

- Organisational risk resulting from the nature of the organisation, i.e. reluctance to change and difficulties in accessing the organisation's resources in the course of project implementation. In the scope of this category, it is also necessary to take into account the financial consequences of the project implementation, and in case of R\&D project the risk connected with knowledge transfer and cooperation with the larger number of entities, i.e. universities or research organisation representing differences in goals and approaches,

- External risk resulting from the impact of factors outside the organisation, e.g. legal and regulatory changes,

- Technological risk - any type of uncertainty related to dynamic and variable technological process. Technology risk management is based on a procedure called Technology Assessment (TA), which results from the human - technology - environment relations. This procedure estimates the scope, size and type of all impacts of the activity on the environment and society in short and long periods of time.

Uncertainty regarding the results of R\&D constitutes an element that significantly affects the level of risk. Appropriate coordination of all processes in the project requires the incurring of large financial outlays, as well as the involvement of a large number of employees - in the case of innovative projects, they constitute specialised interdisciplinary teams, which focus on the achievement of assumed objectives. The problems of technological nature emerge, when e.g. there is a need to use or develop a technology that did not exist until now and the lack of which suspends the implementation of basic assumptions. Other characteristics affecting the scale of threats may include: innovation of solutions that requires large financial outlays, or the engagement of rare specialists from unusual fields, the intensity of planned works, which may result in a decrease in the employees' efficiency and reduced motivation to achieve the objectives.

The R\&D projects are characterised by a lack of precise and long-term planning, because it is difficult to predict what can happen during the research works. This results from high complexity of the involved elements. In this case, the risk may concern the following issues: path to solving the research problem may include false footprints, which will significantly prolong the works, the project team may receive a wrong (false) solution, the achieved solution may remain unrecognised, the solution may not be possible at the current state of science and knowledge, the solution may not be available due to the high cost of planned works of the project team, the team may achieve a competitively inferior solution. 
Due to the complexity and correlation of R\&D projects, they are often implemented in the form of consortia. Among others, this results from the fact that the given project exceeds the implementation capacity of one organisation. In this case, there is a hidden possibility of the risk resulting from a lack of good cooperation, different approaches to the problem-solving and associated delays, failure to comply with the agreements and other. The consortium relies on the cooperation of several entities in order to implement the project development of new technologies would not be possible without the support of individuals academic and research centres, which have the necessary intellectual and technical resources essential to create of innovation. It is therefore necessary to strengthen cooperation under knowledge triangle (business, education and research, [4]) and to develop long-term organisational structure like, i.e. clusters. Cluster as a collection of modern, diverse links between enterprises, scientific world, self-regulatory organisation, administration and business support institutions has been recognized in the EU and the world as one of the proven ways to implement the policy of innovation and is described as one of the most effective instruments of development policy at the level of country and region [4].

Creation of an innovative project is only a half-success. The total success is achieved only in the case of introduction of a product or service on the market, its positive acceptance by recipients and increase in demand, which generates the supply. Only in this manner, it is possible to achieve the reimbursement of costs incurred during the implementation of the project or even the achievement of surpluses.

3. Risk estimation methods for the innovative and technological projects

Risk is any possible event, which may take place in the future, while its consequences may cause negative or positive changes in the project. In the case of equating risk with losses, it is determined based on two parameters. Firstly, it is necessary to reasonably assess the probability of occurrence of an event that causes the given risk. Secondly, it is necessary to estimate the size of potential losses resulting from the occurrence of negative events. In order to assess the technological risk, both qualitative (descriptive) and quantitative (empirical) methods can be used. Qualitative risk assessment methods include: risk matrix method, preliminary hazard analysis method with external, internal and other threats, failure mode and effects analysis what-if analysis, safety audit review, etc. [17]

In the case of occurrence of high level of risk - the most expensive and complex plans are used. For the negative ones - avoidance, i.e. leading to the situation, in which the given risk factor has no possibility to occur. For the positive ones - use, i.e. guaranteeing that the given opportunity will become real. For the risks of medium level less expensive, but also less effective. Usually, the avoidance of risk consists of insuring against certain event or transferring the effects of the given risk to a counterparty (e.g. subcontractor). Providing access - reaction used for positive risk factors consists of implementation of the project together with an entity, in which the probability of a given opportunity becoming real is much higher (e.g. consortium participating in a tender, in which we do not meet one of the conditions, however our business partner meets it). In the case of low-level risks, we use acceptance and if the threats will come true, we incur the adequate effects.

Basic activity in the risk management, and in the Risky Project program, is its estimation. Only this way, it is possible to adjust the appropriate strategy of avoidance, mitigation or use of the risk. This can be approached with the use of several methods:

- $\quad$ scenario analysis, where the simplest tactic is to analyse the worst and the best scenario. This consists of presentation and estimation of the risk of many possibilities - usually 3-5 scenarios for which the appropriate actions are adapted,

- using a decision tree method, which presents a sequence of choices, most of which involve risks,

- $\quad$ simulations that constitute the most complicated, however the most precise probabilistic method of risk estimation. Monte Carlo simulations, which are widely used in the Risky Project, allow for a flexible risk assessment, which is the closest to the real state.

4. Examples of risk estimation in the scope of technological project - case study

While using the project management methods in order to assess the risk, the good practices of risk estimation in terms of the size of impact on the project, the probability of occurrence of the given threat, as well as the dotProject application $[10,11]$, an attempt was made to assess the risk for the processes of manufacturing 
aluminum sections [12]. A risk analysis was performed and it was presented in the form of a table of risks (Table 1), for which an assessment was carried out (Table 2). The risk matrix allows for a quick assessment whether the given process is sufficiently protected against the occurrence of problems. If too many risks are located in the red fields of the matrix, then it is necessary to undertake actions and get rid of the potential threats [13]. In the case of analysis of the technological process of extruding sections made of aluminum alloys, there is an insignificant or low probability of threats to the implementation. Estimated result of the analysis falls within the green fields of the risk matrix, which means that there are no serious threats. The identified micro-downtimes do not cause effects, which required intervention. The level of risk do not reach red colour therefore, it is sufficient to control it via standard operations.

Table 1. Table of risks for the manufacture of sections made of aluminum alloys. Source: Own research

\begin{tabular}{|l|l|l|l|l|l|}
\hline No. & Identified risk & $\%$ & $\begin{array}{l}\text { Probability of the risk } \\
\text { occurrence (\%) }\end{array}$ & $\begin{array}{l}\text { Impact of a risk on } \\
\text { the performance }\end{array}$ & Score \\
\hline A & Defects & 28 & Very high 81-100 & Medium & 2 \\
\hline B & Rundown blocking & 19 & High 61-80 & Low & 1 \\
\hline C & $\begin{array}{l}\text { Additional heating of } \\
\text { inputs }\end{array}$ & 10 & Medium 31-60 & Low & 1 \\
\hline D & Jamming & 7 & Low 0-30 & Insignificant & 1 \\
\hline
\end{tabular}

Table 2. Risk matrix for the manufacture of sections made of aluminum alloys.

\begin{tabular}{|c|c|c|c|c|c|}
\hline \multirow{4}{*}{ Consequence } & High & 3 & 6 & 9 & 12 \\
\cline { 2 - 6 } & Average & 2 & 4 & 6 & 8 \\
\cline { 2 - 6 } & Low & 1 & 2 & 3 & Very high \\
\cline { 2 - 6 } & & Low & Medium & High & \\
\cline { 2 - 6 } & & & & & \\
\hline
\end{tabular}

Investment and innovative projects - they use new technologies and thus contribute to maintaining the enterprise's strong position in the long period of time. These projects are associated with the introduction of new products or services (product innovation) on the market, as well as the introduction of a new technological process by the enterprise, which is aimed at offering the previous or new offer. Implementation may involve the need for investment, which increases the implementation risk. Table 3 presents the risk analysis for the implementation of a new production, based on the data and experiences of Grupa Kęty S.A., while Table 4 presents the risk matrix. The lack of knowledge to apply the technology in practice and too high costs of technology commercialisation were qualified as posing a potentially high risk in the case of their occurrence. 
Table 3. Table of risks associated with the implementation of a new product. Source: Own research.

\begin{tabular}{|l|l|l|l|}
\hline Identified risk & $\begin{array}{l}\text { Probability of the } \\
\text { risk occurrence }\end{array}$ & $\begin{array}{l}\text { Impact of a risk } \\
\text { on the project }\end{array}$ & Score \\
\hline $\begin{array}{l}\text { No demand on the market - failure to activate the } \\
\text { system }\end{array}$ & $5 \%$ & high & 3 \\
\hline Exceeding the planned budget & $5 \%$ & low & 1 \\
\hline $\begin{array}{l}\text { Failure to achieve planned business benefits from } \\
\text { the implementation }\end{array}$ & $40 \%$ & medium & 4 \\
\hline Delay of implementation & $10 \%$ & medium & 2 \\
\hline Too long time for implementation & $15 \%$ & low & 1 \\
\hline $\begin{array}{l}\text { Lack of know-how for using the technology in } \\
\text { practice }\end{array}$ & $60 \%$ & high & 6 \\
\hline Too high costs of technology commercialisation & $60 \%$ & high & 6 \\
\hline
\end{tabular}

Table 4. Risk matrix for a new product

\begin{tabular}{|l|l|c|c|c|}
\hline \multirow{5}{*}{ Consequence } & High & 3 & 6 & 9 \\
\cline { 2 - 5 } & Medium & 2 & 4 & 6 \\
\cline { 2 - 5 } & Low & 1 & 2 & 3 \\
\cline { 2 - 5 } & & Low High \\
\cline { 2 - 5 } & \multicolumn{2}{|c|}{ Probability } \\
\cline { 2 - 5 }
\end{tabular}

Table 5 presents the identification and assessment of a risk associated with the occurrence of micro-downtimes, whose data is included in the work [14], as well as other interruptions that reduce the productive working time of machines used for the extrusion of sections made of aluminum alloys. The model of this table was taken from the work [15]. As a result, the risk matrix assessment is presented in Table 6, whereas Table 7 presents the probability assessment of the occurrence of individual events.

The analysis of events, based on a risk matrix, indicates that there is a low probability of production process disruptions. Designations $A, B, C, D, E$ indicate the type of response to the occurring risk.

$A, B, E$ - Mitigation, withdrawal - risk response strategy

E - insurance, TPM - Total Productive Maintenance,

AM - Autonomous Maintenance

B - TPM - Total Productive Maintenance, AM - Autonomous Maintenance

A - monitoring, PDCA (principle of continuous improvement, kaizen)

C, D - acceptance

P-D-C-A, disseminated by circles associated with management through quality and ISO standards concerning the quality management. 
Table 5. Table of risk associated with disruptions in the effective working time of machines, affecting the production efficiency. Source: Own research [14]

\begin{tabular}{|l|l|l|l|}
\hline Score & Description & Designation & Consequence \\
\hline 1 & Very low & A & $\begin{array}{l}\text { Disruptions that can be eliminated by a person performing } \\
\text { the given activity, e.g. micro-downtimes }\end{array}$ \\
\hline 2 & Low & B & $\begin{array}{l}\text { Short-term disruptions, however with the need to inform } \\
\text { about the event, e.g. repairs, minor failures }\end{array}$ \\
\hline 3 & Medium & C & $\begin{array}{l}\text { Disruptions that require longer downtime, e.g. control } \\
\text { system failures, machine / device failures }\end{array}$ \\
\hline 4 & Serious & D & $\begin{array}{l}\text { Disruptions that require reorganisation of the previous } \\
\text { method of operation, e.g. long-term failures or unexpected } \\
\text { downtimes }\end{array}$ \\
\hline 5 & Disastrous & E & $\begin{array}{l}\text { Disruptions that completely prevent the implementation of } \\
\text { basic operations until their removal, e.g. external factors, } \\
\text { catastrophic failures }\end{array}$ \\
\hline
\end{tabular}

Table 6. Risk matrix

\begin{tabular}{|c|c|c|c|c|c|c|}
\hline \multirow{5}{*}{ 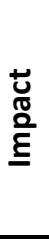 } & Disastrous & 5 & E 10 & 15 & 20 & 25 \\
\hline & Serious & D 4 & 8 & 12 & 16 & 20 \\
\hline & Medium & C 3 & 6 & 9 & 12 & 15 \\
\hline & Low & 2 & 4 & 6 & B 8 & 10 \\
\hline & Very low & 1 & 2 & 3 & 4 & A 5 \\
\hline & & Rare & Unlikely & Medium & Likely & $\begin{array}{l}\text { Almost } \\
\text { certain }\end{array}$ \\
\hline
\end{tabular}

Explanations:

\begin{tabular}{|l|l|l|l|l|l|}
\hline & Low risk & Medium risk & & High risk \\
\hline
\end{tabular}

Table 7. Assessment of the event occurrence probability

\begin{tabular}{|l|l|l|l|l|l|}
\hline Score & $\mathbf{1}$ & $\mathbf{2}$ & $\mathbf{3}$ & $\mathbf{4}$ & $\mathbf{5}$ \\
\hline Description & Rare & Unlikely & Medium & Likely & $\begin{array}{l}\text { Almost } \\
\text { certain }\end{array}$ \\
\hline Range of probability & $0-20 \%$ & $21-40 \%$ & $41-60 \%$ & $61-80 \%$ & $81-100 \%$ \\
\hline
\end{tabular}

In the process of continuous improvement of the activities, which prevent the occurrence of catastrophic consequences of the failure to reduce the risk reduction, it is useful to use the Deming circle, which leads to the process of continuous improvement of the organisation by solving the problems faced by it, recommended in many publications and ISO standards. This type of actions are associated with an iterative way of monitoring the process and preventing the possibility of risk occurrence. [18]

\section{Results and discussion}

The proposed solutions of risk management in the project allowed to identify the risk level and to carry out the event probability assessment. Therefore, this is the basis for developing a set of actions for each identified threat. It is necessary to find a method for better control of the threats and their reduction to an acceptable level [5]. The chances of failure can be reduced by appropriate selection of assumptions, technologies, financing and management. Depending on the possibility of application, two threat reduction strategies are used in the project development phase. The first one consists of searching for and improving the sources of information and news about the project. It is definitely beneficial to develop action scenarios, aimed at controlling the threats accepted by the enterprise. It may consist of introduction of the warning systems, i.e. information processing systems 
allowing for quick identification of the emerging hazards and reduction of their consequences. The project should allow to react to the emerging changes during its implementation. The project can be changed under the pressure of external events. In addition, it may be changed because of new information, which entails decisions concerning changes in the method of solving the predicted threats or reacting to the already encountered problems. In the face of new problems, new decisions are often made, which are sometimes inconsistent with previous decisions or which completely question them. This may result in the introduction of changes concerning the implementation of previously determined tasks, e.g. through merging or shortening the time of their implementation.

The last stage of risk management consists of the capitalisation of collected information and experiences in the form of detailed documentation of hazards and potential threats, which occur at the individual stages of project implementation. For this purpose, it is useful to determine the form of risk-related documents, e.g. the form of Risk Management Plan or the Risk Management Book. PZR is a document describing the adopted procedure for controlling the given threat, including the principles and cycle of risk management (applied ideas, principles for identification, estimation and controlling the threats). The documentation of collected information should be kept in a periodic manner (after completion of each stage, from the beginning of project implementation and in its key moments). The threats are assessed in terms of nature of the project, as well as the organisation implementing such project. The risk of projects implemented in small companies with short time of operation and limited financial possibilities is higher. These problems are much better handled by large enterprises with a well-established position on the market. For the former, a failure in the project's implementation may often result in bankruptcy. The financial and organisational potential, as well as experience and trained staff are often crucial in the scope of handling the threats by a given company $[7,8]$.

The second one consists of externalisation - transferring outside (in its entirety or in part) all the encountered threats. Usually, they are directed to: banks in order to protect against the threats of financial nature (insolvency, lack of liquidity, profitability, etc.), and insurance companies in order to protect against the external threats (changes, political threats, economic threats, market threats, natural disasters etc. ), or possibly to the client in order to mitigate some of the guarantees assumed in the project. To a reasonable extent, the enterprise may share the risk among various parties interested in the project (e.g. partners, suppliers, subcontractors, coworkers and even the client) through cooperation and common investment in R\&D.

One of the solution, which stimulate innovation, exchange of knowledge and provide common R\&D, is networking i.e. in EU policy by promoting cluster cooperation, and applying for common grants. In Poland there are 2 of 16 Key National Clusters where entities connected with aluminum sector present active cooperation. One of them is Polish Aluminum Cluster, which was created to envisage cooperation between entrepreneurs focused on innovation and development, operating in the aluminum industry as well as research institutions and centres, which ensure regular contact with the most up-to date research solutions and the highest level of the quality control. Cluster's member are both business support institutions and enterprises operating in the industry [21]. The second is The Waste Management and Recycling Cluster (www.klasterodpadowy.com), aims to increase competitiveness, effectiveness of using possessed resources and the exchange of knowledge. It offers the possibility of implementing innovative products onto the market by the companies belonging to the cluster. The main scope is to deliver basic information and encourage SME's, public organisations and scientific institutions towards a common research and projects in circular economy economy and zero waste strategy [3]. Partners of the Waste Management and Recycling Cluster are active in KIC Raw Material by for example realisation common "Competitive Sustainable Business from Metal Recycling (BizMet)". BizMet project (2018-2020), which initiates a platform to bring together all regional actors within European countries to accelerate the transformation into circular economy for a sustainable future. It provides an interactive education, networking and knowledge sharing opportunity in the field of metal recycling especially for small and medium enterprises (SMEs), industrial experts, professionals, researchers/scientists, and graduated students. It is also a field for cooperation with to promote the metal mining and recycling industrials into circular economy by improving cooperation between SMEs and universities, understanding of sectoral needs and introducing cutting edge technologies, and to support Polish cluster German - i.e. REWIMET e.V. cluster, which combines as a local association SMEs, industrial partners, municipalities, business developers and universities in the field of recycling/recovery of secondary raw materials. The main regional focus of REWIMET covers the Harz mountain area (lower Saxony, Saxony-Anhalt and Thuringia). The Bizmet project was also a base for creation a next

https://doi.org/10.32933/Actalnnovations.34.6 • ISSN 2300-5599 • C 2019 RIC Pro-Akademia - CC BY 
one supported by NAWA (International cooperation for Rational Use of Raw Materials and Circular Economy), which shows good example for possible cooperation between science and business to exchange knowledge and to reduce risk of future cooperation.

The novelty of this paper is to show for the first time the real risk assessment of the whole production process of aluminum alloys at Kęty SA the largest company of aluminum processing in Poland. The proposed method was implemented to assess the production process and to introduce possible changes when needed. Moreover, it was analysed the potential profit from participation in the national and international projects as a possible aspects which can minimise the risk due to better knowledge of market and possibilities of obtain support for more detailed research. The role of minimisation risk via cooperation between business and industry has not been evaluated as it is of foreseen for the next research.

\section{Conclusions}

Risk management constitutes an important element of every project. Especially, this problem is emphasised in the project management with the use of Prince 2 method. All undertakings require an assessment of risk, which can occur in any given situation. There are methods for the risk estimation, however due to the lack of absolutely certain output data, the conducted assessment must be subject to continuous verification and monitoring. It is not possible to predict situations independent of the enterprise's business activity, e.g. emergence of various external factors, which may disrupt the production process.

The results of risk analyses in the scope of innovative and technological processes indicate that too high commercialisation costs and the lack of appropriate knowledge are essential for the implementation of this type of projects. Based on qualitative risk analysis [9], that the risk factors with the highest probability of occurrence included: unreal project schedule, frequent changes in requirements, error in the estimation of project value (time, costs, etc.), technical problems, and lack of perception of the projects implemented in the enterprise in terms of project portfolios. Whereas, the risk factors with the greatest severity of consequences include incorrect identification of needs, unrealistic project schedule, insufficient competence of the project manager, change in the project's objectives, selection of inappropriate project.

Reduction of risk, in response to the occurred event, may take the form of [6]:

- risk avoidance - consisting of such change in the project that will eliminate the event's impact on the project. Resigning from the project is the final type of risk avoidance,

- risk reduction - consisting of reducing the impact of an event or the probability of occurrence of a cause of the given risk,

- transfer - involvement of a third party in order for it to take the responsibility (usually financial) for possible materialisation of the given risk. Example: purchase of an insurance policy,

- $\quad$ sharing the risk by the involvement of an external organisation, so that it has a share in profits/losses; example: a contract in which the payment for the delivered system depends on the number of completed transactions,

- risk acceptance - consisting of taking no action, except for the observation of status of the risk,

- seizing the opportunity - consisting of using the emerging possibility, strengthening the opportunity by using the emerging chance,

- rejecting the opportunity - consisting of intentional not using the chance emerging in the project.

It was also shown, that networking and cooperation with international projects can create a good base for risk limitation. Nowadays there are a lot of risk management software, however none of them are dedicated particularly to research projects as they are not standardised.

It must be emphasised that in every kind of projects risk estimation is of subjective nature, therefore it is important that it is carried out by competent and decision-making persons, who can (due to the iterative nature of this procedure) take appropriate remedial measures and prevent any possible adverse changes. Thus, it can be concluded that based on the literature data analysis, own experiences, assessment of the impact of events on the production, as well as analysis of individual cases, it is possible to estimate the risk in the implemented technological projects. Full risk management is associated with the need to develop emergency plans and preventive measures that allow for controlling of the risk.

\section{Conflict of interests}

There are no conflicts to declare. 


\section{Acknowledgments}

The issue of this publication is financed by the AGH subsidy for maintaining and developing the research potential, and Bizmet Competitive sustainable business from metal recycling KIC project, and NAWA International cooperation for Rational Use of Raw Materials and Circular Economy.

\section{References}

[1] M. Trocki red., Metodyki zarządzania projektami, Bizarre, Warszawa. 2011.

[2] C. Pritchard, Zarządzanie ryzykiem w projektach, Wig-Press, Warszawa, 2001, PRINCE2, Crown 2009 oraz PMBoK Guide, PMI 2008.

[3] M. Smol, J. Kulczycka, Towards innovations development in the European raw material sector by evolution of the knowledge triangle, Resource Policy 62, 2019.

[4] A. Mrotzek-Bloess, A. Haas, D. Goldmann, J. Nuortila-Jokinen, J. Kulczycka, M. Smol, E. Pędziwiatr, M. Petranikova, B. Ebin, On the way to a circular economy: obstacles and challenges in the metal value chain, Sardinia 2019, 17th International waste management and landfill Symosium

[5] A. Siewiera, Zarządzanie ryzykiem w projektach inwestycyjnych, Zeszyty Naukowe Uniwersytetu Szczecińskiego, No 855 Finanse, Rynki Finansowe, Ubezpieczenia No 74, 1, 2015, DOI: 10.18276/frfu.2015.74/147

[6] M. Prywata, Zarządzanie ryzykiem w małych projektach, Polska Agencja Rozwoju Przedsiębiorczości (PARP), Warszawa, 2010.

[7] K. Janewicz, P. Janewicz, Analiza ryzyka w projektach, Białystok, Towarzystwo Amicus, Europe directBiałystok, 2012.

[8] T. Kaczmarek, Zarządzanie ryzykiem. Ujęcie interdyscyplinarne, Difin, Warszawa, 2010.

[9] M. Magoń, S. Tchórzewski, Zeszyty Naukowe Politechniki Śląskiej, Jakościowa Analiza Ryzyka w Projektach Sektora Prywatnego, 40, 2014, Nr kol. 1909.

[10] A. Damodaran, Ryzyko strategiczne, WAIP - Wydawnictwa Akademickie i Profesjonalne, 2009.

[11] dotProject, [Access: 13.01.2020]: http://dotproject.net.pl/node/58

[12] R. Hubicki, Wpływ parametrów procesowych na efektywność produkcji kształtowników ze stopów aluminum, praca doktorska, Akademia Górniczo - Hutnicza, Kraków, 2019.

[13] W. Tarczyński, Zarządzanie ryzykiem, PWE, Warszawa, 2001.

[14] R. Hubicki, M. Richert, W. Kaczmarczyk, Wpływ mikroprzestojów na efektywność produkcji, Zarządzanie przedsiębiorstwem : Teoria i Praktyka : XVIII międzynarodowa konferencja naukowa : Kraków, 21-22 czerwca 2018 : abstrakty / red. J. Kulczycka, P. Łebkowski. - Kraków : Wydawnictwa AGH, 2018. - ISBN: 978-83-6601630-9.

[15] A. Landwójtowicz, R. Knosala, Analiza czynników ryzyka w przedsięwzięciu innowacyjnym na wybranym przykładzie, [Access: 13.01.2020]: www.wne.sggw.pl/czasopisma/pdf/EIOGZ_2011_nr88_s185-194.pdf

[16] A. Hamrol, W. Mantura, Zarządzanie jakością - teoria i praktyka, Wydawnictwo Naukowe PWN, Warszawa, 2002.

[17] A. Mazur, H. Gołaś, Zasady, metody i techniki wykorzystywane w zarządzaniu jakością, Wydawnictwo Politechniki Poznańskiej, Poznań, 2010.

[18] I. Kędzierska-Bujak, Wykorzystanie cyklu Deminga do podnoszenia jakości nauczania rachunkowości na uczelniach oraz modyfikacji specjalności na kierunku Finanse i Rachunkowość, Zeszyty Naukowe Uniwersytetu Szczecińskiego nr 765 Finanse, Rynki Finansowe, Ubezpieczenia 61, 2013.

[19] E. Różańska, Rachunkowość w zarządzaniu projektami innowacyjnymi, Poznań, 2012, [Access: 13.01.2020]: http://www.wbc.poznan.pl/Content/241066/Ewa\%20R\%C3\%B3\%C5\%BCa\%C5\%84ska\%20Rozprawa\%20doktor ska.pdf

[20] J. Shin, S. Lee, B. Yoon, Identification and Prioritisation of Risk Factors in R\&D Projects Based on an R\&D Process Model, Sustainability MDPI, 2018.

[21] Cluster's genesis, Polish Aluminium Cluster - the origin of the creation, [Access: 13.01.2020]: http://www.polskiealuminium.pl/en/cluster/cluster-s-genesis.html 